\title{
Rules Over Rights? Legal Aspects of the European Commission Recommendation for Resumption of Dublin Transfers of Asylum Seekers to Greece
}

\author{
Boryana Gotsova*
}

(Received 18 June 2018; accepted 30 October 2018)

\begin{abstract}
Five years after the Dublin transfers of asylum seekers to Greece were halted-due to recurrent failings in the detention conditions, living conditions, and asylum procedure-the European Commission recommended a resumption of the practice. This Article analyzes the Recommendation in light of the human rights reports preceding and following it. The examination reveals that the renewal of systematic transfers would be premature, posing serious risks to the rights of asylum seekers under European and EU law. The restoration of a flawed system for distribution of asylum claims among the Member States-without fundamental reforms towards greater solidarity-may lead to a repetition of past mistakes. Despite the paramount importance of the Dublin system for the functioning of the Schengen Area, rule enforcement should not supersede human rights protection.
\end{abstract}

Keywords: European asylum law; Common European Asylum System; Dublin transfers; human rights

\section{A. Introduction}

Amid the most massive displacement of people since the end of the Second World War, ${ }^{1}$ the European Union is experiencing an identity crisis. The integration project-which largely emerged out of a determination to establish peaceful cooperation on the continent-has long prided itself on its commitment to a set of shared values: Freedom, democracy, and human rights. Indeed, the promotion of human rights has been strengthened over the years as a core component of the Union's self-image and outward projection, notably through the Charter of Fundamental Rights of the EU, the pledge to accede to the European Convention for the Protection of Human Rights and Fundamental Freedoms, ${ }^{2}$ the creation of the Fundamental Rights Agency, ${ }^{3}$ and the position of an EU Special Representative for Human Rights. ${ }^{4}$ The migration inflow in recent years,

${ }^{\star}$ The author works in the area of public affairs. She holds a PhD in Public International Law from Sofia University "St. Kliment Ohridski," Bulgaria, and an L.L.M. in European Law from Leiden University, in the Netherlands. The author can be contacted by email at b.gotsova@gmail.com.

${ }^{1}$ U.N. High Commissioner for Refugees, Global Trends: Forced Displacement in 2015, 2015 UNCHR Global TrEnds 5 (June 20, 2016), http://www.unhcr.org/576408cd7.

${ }^{2}$ Consolidated Version of the Treaty on European Union art. 6(2), June 7, 2016, 2016 O.J. (C 202) 13.

${ }^{3}$ Council Regulation 168/2007 of Feb. 15, 2007, Establishing a European Union Agency for Fundamental Rights, 2007 O.J. (L 53) 1 (EC).

${ }^{4}$ Council Decision 2012/440/CFSP of July 25, 2012, Appointing the European Union Special Representative for Human Rights, 2012 O.J. (L 200) 21 (EU).

(C) 2019 The Author. Published by Cambridge University Press on behalf of the German Law Journal. This is an Open Access article, distributed under the terms of the Creative Commons Attribution-NonCommercial-NoDerivatives licence (http://creativecommons.org/licenses/by-ncnd/4.0/), which permits non-commercial re-use, distribution, and reproduction in any medium, provided the original work is unaltered and is properly cited. The written permission of Cambridge University Press must be obtained for commercial re-use or in order to create a derivative work. 
however, has tested not only the Union's institutional capacity to undertake coordinated action, but also the Member States' resolve to adopt a single policy, rather than unilateral measures based on notions of national interest. A case in point is the approach towards the transfers of applicants for international protection under the Dublin system.

The original Council Regulation 343/2003, ${ }^{5}$ also known as the Dublin II Regulation, established the system for review of applications by asylum seekers entering the European Community. This Regulation provided that the Member State constituting the first point of entry for asylum seekers who irregularly crossed the Community borders would be the one responsible for the review of their applications. ${ }^{6}$ As could be expected for purely geographical reasons, that rule put an excessive strain on the external border Member States in times of intensive inflow, ${ }^{7}$ particularly the southern ones. While the resulting inability of an individual country to ensure proper respect for human rights in the treatment of asylum seekers could previously be viewed as a national problem, the Dublin system turned it into a Community challenge. As the European Court of Human Rights (ECtHR) ruled in the well-known case of M.S.S. v. Belgium and Greece, ${ }^{8}$ Greece was not the only one to bear responsibility for infringements of the Convention for the Protection of Human Rights and Fundamental Freedoms - the European Convention on Human Rights. In that particular situation, the conditions of detention, the living conditions, and the asylum procedure to which an Afghan asylum seeker was subjected amounted to human rights violations on the part of the Greek state. The Belgian authorities, however, also committed an infringement by sending the asylum seeker back to Greece and exposing him to the above listed treatment, despite indications that his rights might be breached.

Entering judicial dialogue, in Joined Cases C-411/10 \& C-493/10 N.S., ${ }^{9}$ the Court of Justice of the European Union (CJEU) relied on the ECtHR's findings in the M.S.S. judgment to conclude that the transfer of asylum seekers under the Dublin system, in the face of evidence of a country's inability to uphold its human rights obligations, would constitute an infringement of the Charter of Fundamental Rights of the EU. Furthermore, both Courts rebutted presumptions underlying the functioning of the Dublin system of transfers. The ECtHR established that the presumption of equivalent protection, which could insulate Community acts from review, ${ }^{10}$ did not apply because Belgium exercised its discretion in deciding to send the applicant back without taking into account Greece's track-record in asylum matters. ${ }^{11}$ That was a marked departure from the Court's established jurisprudence. In earlier cases, despite indications of certain failings, the ECtHR had rejected the claims of asylum seekers, choosing instead to rely on certain assumptions about the level of protection in the country responsible for the asylum claim under the Dublin rules, as well as about the general respect for fundamental rights within the EU asylum system. ${ }^{12}$ With regard to suppositions, the CJEU held that European Union law precludes-in the application of Council Regulation 343/2003 - the use of a "conclusive presumption" that the other

\footnotetext{
${ }^{5}$ Council Regulation 343/2003 of Feb. 18, 2003, Establishing the Criteria and Mechanisms for Determining the Member State Responsible for Examining an Asylum Application Lodged in One of the Member States by a Third-Country National, 2003 O.J. (L 50) 1 (EC) [hereinafter Council Regulation 343/2003].

${ }^{6} I d$. art. 10(1). Although several other criteria hierarchically precede the one on irregular entry, this is the provision primarily used for determination of state responsibility.

${ }^{7}$ See also Maarten den Heijer, Jorrit Rijpma \& Thomas Spijkerboer, Coercion, Prohibition, and Great Expectations: The Continuing Failure of the Common European Asylum System, 53 Common MKT. L. Rev. 607, 615 (2016).

${ }^{8}$ M.S.S. v. Belgium and Greece, 2011 I Eur. Ct. H.R. 255.

${ }^{9}$ ECJ, Joined Cases C-411/10 \& C-493/10, N.S. v. Secretary of State for the Home Department, ECLI:EU:C:2011:865, Judgment of 21 Dec. 2011.

${ }^{10}$ Bosphorus Hava Yolları Turizm \& Ticaret Anonim Şirketi v. Ireland, 2005 VI Eur. Ct. H.R. 107.

${ }^{11}$ M.S.S., 2011 I Eur. Ct. H.R. at para. 340.

${ }^{12}$ See Evelien Brouwer, Mutual Trust and the Dublin Regulation: Protection of Fundamental Rights in the EU and the Burden of Proof, 9 Utrecht L. Rev. 135, 139-140 (2013); Cathryn Costello, Dublin-case NS/ME: Finally, an End to Blind Trust Across the EU?, 2 Asiel en Migrantenrecht 83, 84-85 (2012); Violeta Moreno-Lax, Dismantling the Dublin System: M.S.S. v. Belgium and Greece, 14 Eur. J. Migration \& L. 1, 6-17 (2012).
} 
Member States would comply with their human rights obligations under international law simply because they are parties to a set of human rights instruments. ${ }^{13}$ This double imposition of a duty to refrain from transfers-in the presence of signs that human rights violations might ensue-effectively undermined the trust-based Dublin system, leading to the suspension of transfers to Greece since 2011. ${ }^{14}$

Aside from that practical consequence, the legal significance of the two judgments lies in the admission that presumptions shall no longer be observed uncritically. The existence of legal obligations under EU or international instruments on human rights protection shall not suffice to shield a country from rigorous review of its practices. This conclusion has implications at the individual level of asylum seekers, but also at the Union level of interaction among the Member States. As Evelien Brouwer has highlighted, mutual trust has been of paramount importance for the operation and development of the EU for decades, in areas as diverse as the Internal Market, civil and criminal law, and asylum policy. ${ }^{15}$ Other authors have interestingly specified that in asylum law, the mutual recognition resulting from the implicit trust has a negative nature in that a Member State accepts the rejection of others to bear responsibility for an asylum seeker's claim. ${ }^{16}$ Once this recognition system and underlying trust have been called into question, the issue of state responsibility for asylum claims resurfaces, along with an unexpected set of tasks for the inner Member States. Nevertheless, the removal of the absolute nature of mutual trust has been lauded by the academia as progress towards stronger rights protection. ${ }^{17}$ It was assumed that Dublin transfers to Greece would be halted until Greece could demonstrate compliance with its obligations to respect and uphold human rights.

From the perspective of the relationship between the European Convention on Human Rights and EU law, the M.S.S.-N.S. sequence demonstrates the effort of the CJEU to ensure congruence between its reading of the Charter of Fundamental Rights of the EU and the ECtHR's interpretation of the Convention. Some authors have praised the CJEU's reaction to M.S.S., highlighting the dangerous possibility of conflict between the two legal orders, which was skillfully averted. ${ }^{18}$ Others have criticized the CJEU for performing only the bare minimum when adapting its rulings to the ECtHR level, without seizing the opportunity to infuse the Charter provisions with a greater protection scope. ${ }^{19}$ To be sure, Article 52(3) of the Charter of Fundamental Rights of the EU creates an obligation to give equivalent meaning to those rights listed in it that correspond to rights enshrined in the Convention, without precluding stronger protection by the EU. ${ }^{20}$ It seems, however, that the threat of divergent interpretations will be a lasting, rather inevitable feature of the multi-level human rights system in Europe, which encompasses national courts, the Union, and the ECtHR. ${ }^{21}$ Conformity between the European Convention on Human Rights and Union law should not be taken for granted because it requires constant attention and accommodation, especially on the part of the CJEU. The maintenance of a close relationship is necessary for the sake of

\footnotetext{
${ }^{13}$ N.S., Cases C-411/10 \& C-493/10 at paras. 99-105.

${ }^{14}$ Commission Recommendation 2016/2256 of Dec. 8, 2016, Addressed to the Member States on the Resumption of Transfers to Greece Under Regulation (EU) No 604/2013 of the European Parliament and of the Council, recital 1, 2016 O.J. (L 340) 60 (EU) [hereinafter Recommendation 2016/2256].

${ }^{15}$ Brouwer, supra note 12 , at 136.

${ }^{16}$ Costello, supra note 12, at 90-91; Valsamis Mitsilegas, Solidarity and Trust in the Common European Asylum System, 2 Comp. Migration STUd. 181, 184 (2014).

${ }^{17}$ Brouwer, supra note 12, at 145-46 (endorsing the introduction of what she terms "rebuttable trust"); see also Costello, supra note 12 , at 90 .

${ }^{18}$ See Paul Gragl, The Shortcomings of Dublin II: Strasbourg's M.S.S. Judgment and Its Implications for the European Union's Legal Order, 12 Eur. Y.B. Hum. RTs. 123 (Wolfgang Benedek et al. eds., 2012). The page citations in this Article refer to the version available at https://papers.ssrn.com/sol3/papers.cfm?abstract_id\%3d2183677; see 8-9.

${ }^{19}$ See Costello, supra note 12, at 91-92.

${ }^{20}$ Charter of Fundamental Rights of the European Union art. 52(3), June 7, 2016, 2016 O.J. (C 202) 389.

${ }^{21}$ Brouwer, supra note 12 , at 147 .
} 
legal certainty-for both asylum seekers and the Member States, which are all parties to the Convention. The reassertion of this interpretative coherence is therefore commendable.

As to the aftermath of the two judgments, following several years of situation monitoring within the frameworks of the Council of Europe $(\mathrm{CoE})$ and the European Union, on December 8, 2016, the European Commission recommended the resumption of transfers to Greece as of March 15, 2017 under the recast Dublin system for most asylum applicants with the exception of vulnerable ones such as unaccompanied minors. ${ }^{22}$ This Article will analyze the Commission's conclusion in the light of the ECtHR's reasoning in the M.S.S. judgment, taking into account the latest developments in Greece regarding the treatment of asylum seekers. The examination will reveal that the three aspects for which Greece was sanctioned back in 2011detention conditions, living conditions, and asylum procedure-were problematic at the time of issuance of the Recommendation and remain such to the point of casting serious doubts on the compatibility of transfer resumption with human rights protection. As this Article will demonstrate, this finding is particularly disturbing given the current political pressure for transfers to Greece and the lack of ambition for fundamental reforms in the recasting of the Dublin rules.

\section{B. Detention Conditions}

The first violation established by the ECtHR in M.S.S. v. Belgium and Greece was the detention of the applicant in conditions constituting degrading treatment contrary to Article 3 of the European Convention on Human Rights. ${ }^{23}$ The chief elements of the infringement were the immediate detention without explanation, ${ }^{24}$ ill-treatment by the authorities, and debasing physical conditions consisting in prolonged indoor confinement in an overcrowded space without the requisite access to properly maintained sanitary facilities. ${ }^{25}$ The Court dismissed the authorities' argument about the minimum level of severity implicit in Article 3 of the Convention. ${ }^{26}$ The two periods for which the applicant was held in detention-four days and one week respectively-were considered sufficient to engage the Greek state's responsibility under the Convention. In reaching the above conclusions, the ECtHR was not too exacting towards the evidence supplied by the applicant. Even though some of the applicant's claims could not be corroborated by documental evidence, the Court found support for them in the reports of human rights observers who had recorded the testimonials of other asylum seekers subjected to analogous treatment. ${ }^{27}$ In fact, the on-site reports of international organizations-for example, the United Nations High Commissioner for Refugees (UNHCR) and the European Committee for the Prevention of Torture and Inhuman or Degrading Treatment or Punishment-along with reports from various non-governmental organizations (NGOs) such as Amnesty International, Human Rights Watch, and the European Council on Refugees and Exiles - were regarded by the Court throughout the judgment as reliable sources of context and indicators of the general practices applied by the authorities. ${ }^{28}$ In implementing

\footnotetext{
${ }^{22}$ Recommendation 2016/2256, supra note 14, at pt. 9. Because the M.S.S. and N.S. judgments did not concern the particular situation of unaccompanied minors, and because the Commission specifically excludes vulnerable applicants from the scope of transfer resumption, those situations are not examined in the current Article.

${ }^{23}$ M.S.S., 2011 I Eur. Ct. H.R. at para. 233.

${ }^{24}$ It is worth noting that according to Laurens Lavrysen, the Dublin system itself was conducive to the extensive practice of detaining asylum seekers. Laurens Lavrysen, European Asylum Law and the ECHR: An Uneasy Coexistence, 4 GoETTINGEN J. INT'L L. 197, 240 (2012).

${ }^{25}$ M.S.S., 2011 I Eur. Ct. H.R. at paras. 225-30.

${ }^{26} \mathrm{Id}$. at para. 232; see also id. at paras. 211, 219-20.

${ }^{27} I d$. at para. 227.

${ }^{28}$ See, e.g., M.S.S., 2011 I Eur. Ct. H.R. at paras. 226, 229-30.
} 
the Court's judgment, Greece presented and undertook a series of measures for bringing the conditions at detention centers in line with the requisite standards. ${ }^{29}$ It is against this backdrop that the current situation in Greece is to be critically examined.

The first point of reference is the Commission Recommendation, which one may expect to provide a solid overview of the facts leading to the proposal for resumption of transfers. Nonetheless, the Commission was rather laconic, admitting that unaccompanied minors might still find themselves detained "for prolonged periods" and urging for the resolution of that problem. ${ }^{30}$ While the Commission avoided a discussion on the issue of detention, the institution recognized that further efforts were needed on the part of Greece for the provision of open accommodation, both permanent and temporary. ${ }^{31}$ This implies persisting actual confinement of asylum seekers, which needs to be remedied.

In addition, the Commission acknowledged that the UNHCR had been instrumental in providing a very significant number of places in open accommodation-20,145 as of December 6, 2016 - through a Delegation Agreement expiring at the end of 2016. ${ }^{32}$ Although the Commission expressed hopes for an extension of the project, no definite result was achieved at the time of the Recommendation, ${ }^{33}$ making the Recommendation seem rather premature. Furthermore, the Commission should have acknowledged that the scheme in question did not constitute a performance of Greece's obligation to avoid the automatic detention of asylum seekers. The considerable increase of the available open accommodation places does not signify Greece's capacity to reduce the incidence of detention. The use of a successful externally-funded project to affirm the state's ability to ensure proper human rights protection has the potential to distort the assessment.

The European Commission's account deeply contrasts with the assessments of third-party observers, issued just months prior to the Recommendation. Considering the crucial evidential weight that was given to human rights reports in the M.S.S. judgment, the on-site evaluations of international organizations (IOs) and NGOs should not be underestimated. It is appropriate to start with the joint analysis by the International Commission of Jurists and the European Council on Refugees and Exiles, submitted to the CoE Committee of Ministers in March 2016 in connection with the implementation of Greece's commitments arising from the judgment. ${ }^{34}$ The report casts doubt on the Greek detention statistics due to the unavailability of complete and full data. ${ }^{35}$ Furthermore, the two organizations argued that the European Commission accepted the national authorities' excessively wide concept of "open accommodation," so that facilities, which restrict asylum seekers' freedom to the point of detention, were nevertheless termed and counted as reception centers. ${ }^{36}$ Similarly, the submission of the Greek Council for Refugees from the spring of 2016 pointed out that the number of detainees at police stations

\footnotetext{
${ }^{29}$ Department for the Execution of Judgments of the European Court of Human Rights, M.S.S. against Belgium and Greece, CouncIL OF Eur. para. 22 (May 29, 2012), https://search.coe.int/cm/Pages/result_details.aspx?ObjectID\%3d09000016 $805 \mathrm{~b} 7 \mathrm{~d} 90$ [hereinafter Dep't for the Execution of Judgments].

${ }^{30}$ Recommendation $2016 / 2256$, supra note 14 , at recital 28 , pt. 1 (e).

${ }^{31} I d$. at recital 14 , pt. 1 .

${ }^{32} I d$. at recital 11 .

${ }^{33}$ Later on, the UNHCR and the European Commission's Directorate-General for European Civil Protection and Humanitarian Aid Operations teamed up under the banner of the Emergency Support to Integration \& Accommodation (ESTIA). The program for asylum seekers and refugees has provided $€ 304$ million since 2017 for urban accommodation and monthly cash grants. See Greece, Eur. Civil Prot. \& Humanitarian Aid Operations (Jan. 29, 2019), http://ec.europa. eu/echo/where/europe/greece_en.

${ }^{34}$ Secretariat of the Comm. of Ministers, Communication from NGOs (InTERnational Commission of Jurists (ICJ) And European Council on Refugees and Exiles (ECRE)) (29/03/2016) in the Case of M.S.S. Against GreeCE (APPliCATION No. 30696/09) (2016), https://rm.coe.int/1680644726 [hereinafter COMMUNiCATION FROM ICJ \& ECRE].

${ }^{35} I$. at 11 .

${ }^{36} I d$. at 8,10 .
} 
was unknown, ${ }^{37}$ which undermined the efforts to estimate the scale of detention. The Greek Council for Refugees also noted that the number of detainees had been on the rise, and that persons arriving after the entry into force of the EU-Turkey Statement ${ }^{38}$ were subjected to "automatic detention" 39 - a troubling fact corroborated by Amnesty International in its May 2016 submission. ${ }^{40}$ The on-site findings of human rights observers strongly indicate that the practice of detention was still widespread and, at least at certain times, automatic, thus raising concerns about its compatibility with the European Convention on Human Rights.

The assessments of NGOs and international organizations on the conditions of detention are also in stark contrast with the suggestion to renew the operation of the Dublin system. As of May 2016, the Greek Council for Refugees reported "substandard" conditions both on the mainland and on the islands - testifying to overcrowding, lack of food and medical services, poor sanitation, unavailability of interpretation services, and significant risks for the basic safety of individuals. ${ }^{41}$ The account of detention conditions, given by Amnesty International, is disturbingly similar. ${ }^{42}$ The International Commission of Jurists (ICJ) and the European Council on Refugees and Exiles (ECRE) considered the statements of the Greek Council for Refugees sufficiently reliable to not only quote them, but to use them as a premise to caution that the detention conditions were not in line with the duties of Greece stemming from the implementation of the M.S.S. judgment. ${ }^{43}$ The Greek Council for Refugees has gone one step further, concluding that the detention conditions on the mainland were "in violation of [the] international and national legal framework." 44 While the compatibility of the detention conditions with the European Convention on Human Rights shall ultimately be evaluated by the ECtHR on a case-by-case basis, the factual evidence gathered by third-party observers on the ground is in no way consistent with an inference that systematic transfers should be resumed. On the contrary, it indicates that the capacity of Greece to comply fully with its human rights obligations needed further reinforcement at the time of issuance of the Commission Recommendation. It stirs serious reservations regarding the preparedness of the country to guarantee rights protection at the requisite level.

\section{Living Conditions}

The second violation of the European Convention on Human Rights, committed by Greece according to the M.S.S. judgment, consisted of the living conditions to which the asylum seeker was exposed. By the applicant's own account, he lived for months in abject poverty, in deprivation of food, shelter, and sanitation, experiencing constant fear for his personal security, and troubled by the unlikelihood of relief. ${ }^{45}$ The Court found ample corroboration for the applicant's testimony in the reports of third-party observers, according to whom it corresponded to "the everyday lot of

\footnotetext{
${ }^{37}$ Secretariat of the Comm. of Ministers, Communication from a NGO (Greek Council for Refugees) (30/05/ 2016) In the CASE of M.S.S. Against Greece (Application No. 30696/09) 10 (2016), https://rm.coe.int/1680667b67 [hereinafter Communication FROM THE GReEK COUNCIL FOR Refugees].

${ }^{38}$ To manage the migration inflow to the EU, it was agreed that all irregular migrants - those not applying for asylum or ineligible for protection-coming from Turkey to the Greek islands as of March 20, 2016 would be returned to Turkey. For every Syrian sent back to Turkey, another Syrian would be resettled from Turkey to the Union. For the full terms of the arrangement, see European Council, EU-Turkey statement, European Council Press Release (Mar. 18, 2016), http:// www.consilium.europa.eu/en/press/press-releases/2016/03/18-eu-turkey-statement/.

${ }^{39}$ Communication from the Greek Council fOr Refugees, supra note 37, at 9-10.

${ }^{40}$ Secretariat of the Comm. Of Ministers, Communication From a NGO (AMNeSTy International) (19/05/2016) IN THE CASE OF M.S.S. Against GREeCE (Application No. 30696/09) 6-7 (2016), https://rm.coe.int/1680667a9f [hereinafter COMMUNICATION FROM AMNESTY INTERNATIONAL].

${ }^{41}$ Communication from the Greek Council for Refugees, supra note 37, at 10-13.

${ }^{42}$ COMMUNICATION FROM AMNESTy INTERNATIONAL, supra note 40 , at 8 .

${ }^{43}$ COMMUNICATION FROM ICJ \& ECRE, supra note 34, at 13.

${ }^{44}$ Communication from the Greek Council for Refugees, supra note 37, at 10.

${ }^{45}$ M.S.S., 2011 I Eur. Ct. H.R. at para. 254.
} 
a large number of asylum seekers with the same profile."46 Taking into consideration the vulnerable position of asylum seekers, the insufficient reception capacity in Greece, the immense practical difficulties of finding employment to lift himself out of poverty, and the slow review of his asylum application, the Court considered the state responsible for a violation of Article 3 of the Convention. ${ }^{47}$ Therefore, the conformity between the narrative of the applicant and the NGO/IO statements, together with the level of his suffering, justified the finding of an infringement. As some authors have pointed out, the establishment of a violation regarding the living conditions is a precedent in itself, raising questions as to the future ECtHR interpretation of socio-economic circumstances within the context of the fundamental rights guaranteed by the Convention. ${ }^{48}$ With regard to the specific case, Greece's commitment for implementing the Court's judgment entailed the provision of a "dignified standard of living"-in other words, first reception centers, which would meet the accommodation, healthcare, and information needs of migrants, while ensuring registration and referral to the asylum application procedure. ${ }^{49}$ It is against the Court's conclusions and Greece's pledges of human rights-compliant reception conditions that the subsequent circumstances must be assessed.

A useful starting point for examining the suitability of the Recommendation is the European Commission's own evaluation of the situation. The institution established that Greece had made considerable progress over the past year in expanding its reception capacity for irregular migrants and asylum applicants. ${ }^{50}$ At the same time, the Commission acknowledged that as of December 5, 2016, the number of registered migrants was nearly twice as high as the number of accommodation places available on the Aegean islands. ${ }^{51}$ Furthermore, the reception facilities were found to "fall short of the requirements stipulated in the Reception Conditions Directive" — on the islands, but also on the mainland - with respect to living space, sanitation, healthcare, and security. ${ }^{52}$ The problems were not only material, but also organizational, as the Commission criticized the overall management of the reception process. ${ }^{53}$ The conclusion-based on the factual situation-was that "Greece still needs to make progress in establishing sufficient and adequate dedicated permanent open reception capacity," meeting the requirements of EU law. ${ }^{54}$ It is exceedingly difficult to reconcile this deduction with the Commission's ultimate recommendation to gradually resume the Dublin transfers. On the one hand, the Commission ascertained that during the country's monitoring within the CoE framework since 2011, with all the EU and international assistance provided, Greece had not fully guaranteed adequate reception conditions. On the other hand, the Recommendation expressed hopes that the situation would be remedied in three months' time, when the renewal of transfers should be permitted.

To place the situation in a more extensive legal context, it is vital to recall that under Article 18(9) of the Reception Conditions Directive, ${ }^{55}$ deviations from the EU standards for material reception conditions shall be permitted in exceptional circumstances, for the briefest period possible, and only if they meet the applicant's basic needs. The mandatory nature of these standards is additionally emphasized by Regulation 604/2013 — the so-called Dublin III Regulation-which in

\footnotetext{
${ }^{46} I d$. at para. 255 .

${ }^{47} I$ d. at paras. $258-64$

${ }^{48}$ Gina Clayton, Asylum Seekers in Europe: M.S.S. v Belgium and Greece, 11 HuM. RTs. L. Rev. 758, 765-69 (2011); Costello, supra note 12, at 85-86; Lavrysen, supra note 24, at 226-31.

${ }^{49}$ Secretariat of the Comm. of Ministers, Communication by Greece Concerning the Case of M.S.S. AGainst BELGIUM AND GREECE 5-7 (2011), https://rm.coe.int/168063cb6f (speaking of “un niveau de vie digne," translated as "a dignified standard of living”) [hereinafter ACTION Plan-COMMUNiCATION BY GREeCE].

${ }^{50}$ Recommendation 2016/2256, supra note 14, at recital 9.

${ }^{51} I d$.

${ }^{52} I d$. at recital 12 .

${ }^{53} \mathrm{Id}$. at recital 13 .

${ }^{54} \mathrm{Id}$. at recital 14 .

${ }^{55}$ Directive 2013/33/EU, of the European Parliament and of the Council of 26 June 2013 Laying Down Standards for the Reception of Applicants for International Protection, 2013 O.J. (L 180) 96.
} 
effect provides that transfers to the Member State of first entry shall not be carried out when there are indications of "systemic flaws" in the reception conditions "resulting in a risk of inhuman or degrading treatment." 56 This provision directly reflects the Union's concern of ensuring the compatibility of its asylum rules with its own and the Member States' obligations under EU and international law. Specifically, the revocation of the presumption of human rights protection stems from the M.S.S. and N.S. judgments. ${ }^{57}$ In the M.S.S. ruling, the ECtHR underlined that the Reception Conditions Directive - in its earlier form-had been transposed into national law, signaling the recognition by the Greek authorities of their heightened obligations with regard to the living conditions for vulnerable groups like asylum seekers. ${ }^{58}$ This duty constitutes a binding responsibility, as affirmed by the ECtHR and CJEU in the two judgments. Non-performance produces concrete legal consequences for the Member State concerned and the entire EU system. Therefore, the Recommendation to resume transfers diminishes the significance that should be afforded to the living conditions standards.

Although the Commission did not consider the shortcomings in the Greek reception facilities grave enough to continue the suspension of transfers, it is necessary to compare that position with the views of third parties. When juxtaposed against the reports of NGOs and IOs, the Commission's account of living conditions might appear rather sparing. On visits to hotspots on some of the Greek islands, representatives of Human Rights Watch found facilities that were "severely overcrowded, with significant shortages of basic shelter and filthy, unhygienic conditions," providing insufficient physical protection and healthcare services. ${ }^{59}$ As of late November 2016, the organization noted that the number of asylum seekers on the five main islands exceeded twice the reception capacity, forcing applicants to live in "overcrowded and abysmal conditions." 60 The provision of adequate reception capacity has been an ongoing problem for Greece, occasionally exacerbated by a sudden surge of the migration inflow. Back on March 1, 2016, a UNHCR spokesman described Europe as being "on the cusp of a largely self-induced humanitarian crisis," primarily referring to the situation in Greece where 24,000 refugees and migrants lacked accommodation at the time.$^{61}$ Despite sustained efforts on the part of the country and its international partners, the living conditions in many of the facilities remained substandard over the course of 2016. Around the time the Commission issued its Recommendation for transfer resumption, the UNHCR reported the following: "[C]ongestion, with dire impacts on living conditions" on the islands, with few facilities providing adequate services on the mainland; shortcomings in guaranteeing security, resulting in psychological pressure on asylum seekers; and scarcity of healthcare services. ${ }^{62}$ Together, these findings do not suggest that Greece had achieved such ostensible and irreversible progress since the M.S.S. judgment in providing proper living conditions as would justify the resumption of systematic transfers.

\footnotetext{
${ }^{56}$ Regulation 604/2013, of the European Parliament and of the Council of 26 June 2013 Establishing the Criteria and Mechanisms for Determining the Member State Responsible for Examining an Application for International Protection Lodged in One of the Member States by a Third-Country National or a Stateless Person, art. 3(2), 2013 O.J. (L 180) 31 (EU) [hereinafter Regulation 604/2013].

${ }^{57}$ For instance, compare $i d$. with N.S., Cases C-411/10 \& C-493/10, at para. 86.

${ }^{58}$ M.S.S., 2011 I Eur. Ct. H.R. at paras. 250-51, 263.

${ }^{59}$ Greece: Refugee “Hotspots” Unsafe, Unsanitary, Hum. RTs. WAтcH (May 19, 2016), https://www.hrw.org/news/2016/05/ 19/greece-refugee-hotspots-unsafe-unsanitary.

${ }^{60}$ Eva Cossé, Lesbos Fatal Blast a Stark Reminder of Hardships Refugees Face in Greece, Hum. RTs. WATCH (Nov. 25, 2016), https://www.hrw.org/news/2016/11/25/lesbos-fatal-blast-stark-reminder-hardships-refugees-face-greece.

${ }^{61}$ UNHCR Warns of Imminent Humanitarian Crisis in Greece amid Disarray in Europe over Asylum, U.N. HIGH COMM’R FOR REFUGEES (Mar. 1, 2016), http://www.unhcr.org/news/briefing/2016/3/56d564ed6/unhcr-warns-imminent-humanitarian-crisisgreece-amid-disarray-europe-asylum.html.

${ }^{62}$ U.N. High Comm'r for Refugees, Regional Refugee and Migrant Response Plan for Europe: January to DECEMBER 2017, at 49-51 (2016), http://www.unhcr.org/partners/donors/589497d07/2017-regional-refugee-migrantresponse-plan-europe-january-december-2017.html.
} 
Another factor to be taken into consideration is the sheer magnitude of the reception capacity required. Although the inflow dropped after the first quarter of 2016-as a result of the EUTurkey Statement-by the end of 2016 the total number of sea arrivals to Greece was 174,500 according to UNHCR data. ${ }^{63}$ This is an enormous figure, considering that Greece must provide at least basic first-line reception conditions to those arriving, in addition to ensuring proper conditions for the people who had reached the country earlier and already applied for asylum or international protection. In 2015, for instance, about 885,000 people reached Europe through Greece, most of whom continued their northwest-bound journey, because, by the European Commission's own account, Greece was unable to register and provide initial reception conditions. ${ }^{64}$ Admittedly, the number of potential asylum seekers remaining in Greece represents a small fraction of total arrivals. Nevertheless, according to data by the statistical office of the EU, in 2016 alone, Greece received 49,875 applications from first-time asylum seekers, which corresponds to an annual surge of $339 \% .{ }^{65}$ By contrast, the country's reception capacity stood at 71,539 places as of December 6, $2016^{66}$ and 74,389 places as of mid-March $2017 .{ }^{67}$ Furthermore, it should be noted that the Commission's reception statistics are disputed by NGOs working on the ground, which have argued that temporary shelters of various kinds are erroneously counted into the reception capacity and that the lack of proper living conditions is a nearly ubiquitous problem. ${ }^{68}$ The substandard conditions in many of the facilities, as testified to by the Commission Recommendation and NGO and IO observations, along with the geographical vulnerability of Greece to migration inflow, pose questions regarding the timeliness of the proposal to restore transfers. It would have seemed more appropriate to give the country a longer reprieve in order to take full stock of the situation and appropriately accommodate the asylum seekers and migrants already on Greek territory before attempting a re-establishment of the Dublin system.

\section{Asylum Procedure}

The third count on which the ECtHR established an infringement by Greece was the inadequacy of the asylum procedure. In this regard, the Court's review was limited to verifying the existence of "effective guarantees... that protect the applicant against arbitrary refoulement, be it direct or indirect," to the country of origin. ${ }^{69}$ The existence of such guarantees comprises several elements: Legal and practical availability; capacity of the remedy to give relief; promptness; and sufficient intensity of the scrutiny and relief in view of the serious risks associated with complaints under Article 3 of the Convention. ${ }^{70}$ Naturally, the Court's assessment in M.S.S. v. Belgium and Greece was driven by the particular circumstances of the case, specifically the applicant's past as an interpreter for international military personnel stationed in Afghanistan, which placed him in potential jeopardy of ill-treatment if sent back to his homeland. ${ }^{71}$ At the same time, the Court found a set of

\footnotetext{
${ }^{63}$ U.N. High COMm’r fOr RefugeEs, Bureau fOr Europe WeEkly Report January 13, 2017, at 1 (2017), https://data2. unhcr.org/en/documents/download/53012 (“Arrivals to Greece and Italy per Month” graph).

${ }^{64}$ EU-Turkey Statement: One Year On, Eur. Commission (Mar. 17, 2017), https://ec.europa.eu/home-affairs/sites/ homeaffairs/files/what-we-do/policies/european-agenda-migration/background-information/ eu_turkey_statement_17032017_en.pdf [hereinafter EuR. COMMISSION].

${ }^{65}$ Asylum in the EU Member States, Eurostat (Mar. 16, 2017), http://ec.europa.eu/eurostat/documents/2995521/7921609/ 3-16032017-BP-EN.pdf.

${ }^{66}$ Recommendation 2016/2256, supra note 14, at recital 9.

${ }^{67}$ Eur. Commission, supra note 64.

${ }^{68}$ Letter from Catherine Woollard, Secretary-General, European Council on Refugees and Exiles, et al. to Jean-Claude Juncker, President, European Commission \& Ioannis Mouzales, Minister of Migration Policy, Greece 6 (Dec. 15, 2016), http://test.solidaritynow.org/wp-content/uploads/2016/12/Letter_CommissionMinistryMigration_final-1.pdf.

${ }^{69}$ M.S.S., 2011 I Eur. Ct. H.R. at para. 286.

${ }^{70} I d$. at paras. $290-93$.

${ }^{71} I d$. at paras. $294-97$.
} 
general deficiencies in the functioning of the asylum procedure, which were corroborated by the accounts of third-party observers and thus considered likely to have occurred ${ }^{72}$ - despite the firm refutations of the Greek authorities. Those shortcomings related to the lack of information and hampered communication between asylum seekers and authorities, the absence of legal counsel, the long duration of the procedure, and the indications of blanket decisions on asylum claims rather than individualized evaluations. ${ }^{73}$ To address the situation, following the judgment, Greece undertook the setup of well-recruited asylum and appeals services, which would ensure that applications are properly processed within a reasonable time and that asylum seekers can exercise their legal rights throughout the procedure. ${ }^{74}$ Meanwhile, transitional measures would significantly reduce the accumulated backlog. ${ }^{75}$ This is the background against which the Commission Recommendation shall be appraised.

In its overview as of late 2016, the Commission pointed out the considerable progress achieved by Greece in a number of aspects related to the asylum procedure, namely the setup of regional asylum offices, the surge in the Asylum Service staff, and the reduction of the appeals backlogfrom 51,000 cases in early 2013 to 6,589 cases as of November $2016 .^{76}$ At the same time, the provision of free legal aid was not fully ensured-notwithstanding Greece's recognition that the exercise of rights by third-country nationals presupposes the use of translation and legal counsel services free of charge. ${ }^{77}$ While the legal framework was in place, legal counsel was largely provided on a project basis through international funding. ${ }^{78}$ In addition, the European Commission admitted that the country still experienced difficulties with accelerating the procedure and clearing the backlog of applications, ${ }^{79}$ although speediness should not be pursued at the expense of applicants' rights. The Commission urged an initial assessment and follow-up reviews of the Asylum Service human resources necessary to respond to the "current and likely future case-load." 80 It would seem logical that such an evaluation would precede the decision to support the gradual resumption of transfers. Instead, the Commission advised reinstatement of the Dublin system - a rather precarious step because it rests on too many assumptions about the completion of required safeguard measures.

Furthermore, the outstanding deficiencies in the asylum system were among the gravest concerns of third-party observers in their last submissions to the CoE Committee of Ministers prior to the Commission Recommendation. For instance, Amnesty International alerted that the legal measures for expediting procedures made "the exercise of an effective remedy impossible or excessively difficult," especially given the overall shortage of free legal aid. ${ }^{81}$ The NGO also pointed to failings in supplying asylum seekers with all of the information pertinent to the processes of application, relocation, and family reunification. ${ }^{82}$ While the authorities established a-rather complexschedule for appointment booking via Skype, the persistent problem with understaffing remained an impediment to the practical submission and processing of asylum requests. ${ }^{83}$ As of April 2016, an increase of the Asylum Service workload, following the EU-Turkey Statement, was registered by Amnesty International based on individual asylum worker testimony. ${ }^{84}$ The official figures of the

\footnotetext{
${ }^{72}$ This was a reversal of the Court's earlier case law, in which the reports of IOs and NGOs were generally disregarded when evaluated against the assertions of states. See Moreno-Lax, supra note 12, at 15-16.

${ }^{73}$ M.S.S., 2011 I Eur. Ct. H.R. at paras. 301-02; see also id. at paras. 304-20.

${ }^{74}$ Dep't for the Execution of Judgments, supra note 29 at paras. 44-45.

${ }^{75} \mathrm{Id}$. at para. 47.

${ }^{76}$ Recommendation 2016/2256, supra note 14, at recitals 15-16, 23.

${ }^{77}$ ACtion Plan-COMmunication By GREeCE, supra note 49 , at 8.

${ }^{78}$ Recommendation 2016/2256, supra note 14, at recital 25.

${ }^{79} \mathrm{Id}$. at recital 17 .

${ }^{80} \mathrm{Id}$. at recitals $17-18$.

${ }^{81}$ COMMUNICATION FROM AMNESTy INTERNATIONAL, supra note 40, at 2.

${ }^{82} \mathrm{Id}$. at 4 .

${ }^{83} \mathrm{Id}$.

${ }^{84} I$ d.
} 
Greek authorities now confirm that initial finding: The country received 51,091 applications in 2016 against 13,195 applications in 2015-a staggering surge of $287 \%$ year-on-year. ${ }^{85}$ In this context, the need for increased staff capacity - before the resumption of transfers, which would exercise additional strain on the Greek asylum system-seems imperative.

Moreover, Amnesty International's evaluation was consistent with the report of the ICJ and ECRE, which concluded that the Skype appointment procedure served as a barrier to application-filing, while the considerable rise of asylum claims in Greece, after the closure of the Balkan route, stretched the human resources of the Asylum Service. ${ }^{86}$ On those grounds, as well as the shortcomings in the length and conduct of the appeals procedure, the ICJ and ECRE considered that Greece was not properly executing the M.S.S. judgment. ${ }^{87}$ In a similar vein, the Greek Council for Refugees found that the application procedure was inaccessible for people already residing in the country and for new arrivals alike-due to the Skype appointment-booking procedure and the sheer overload of the Asylum Service after the closing of the national borders of neighboring countries along the route to Western Europe. ${ }^{88}$ The issue of insufficient staff capacity to process filed applications and appeals was exacerbated by the lack of a functioning national system for free legal aid. ${ }^{89}$ An additional set of problems, surrounding the fast-track procedure for asylum seekers arriving in hotspots after the EU-Turkey Statement, was flagged by the NGO. The Greek Council for Refugees ${ }^{90}$ worried about the possibility for substantive examination of the claims and appeals in overly expedited proceedings and about the contradiction between the management of the procedure and Greece's commitments to comply with the M.S.S. judgment. ${ }^{91}$ In light of these observations and assessments, which closely correspond to the aspects comprising the Convention violation established by the ECtHR in 2011, it seems that Greece was still far from fulfilling all requirements for the safe resumption of transfers.

\section{E. Recent Developments: Work in Progress}

Asylum protection is of a dynamic nature given the multiple variables that come into play, such as: The country's efforts to constantly improve the legal framework and practical implementation; the financial, technical, and administrative support from international partners; and the actual pressure on the system exercised by the ebb and flow of migration. Therefore, it is useful to look at more recent snapshots of the situation, taken by the relevant stakeholders involved with the M.S.S. judgment. These findings and reports serve as a test of the suitability of the Recommendation to resume transfers. While such analysis benefits from hindsight that the Commission lacked at the time of its proposal, the examination thus far has demonstrated that as of December 2016, there were already multiple indicators pointing that the reinstatement of the Dublin system would be premature.

In their March 2017 submission on the execution of the M.S.S. judgment, the Greek authorities presented the country's serious positive steps towards meeting the standards of the European Convention on Human Rights. ${ }^{92}$ In particular, the national authorities had been upgrading the

\footnotetext{
${ }^{85}$ Secretariat of the Comm. Of Ministers, Communication from Greece (15/03/2017) in Response to the DeCision

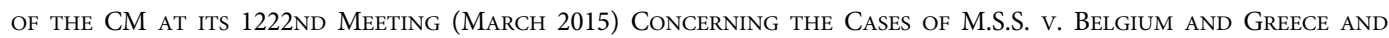
RAHIMI v. Greece (Applications No. 30696/09, 8687/08) (2017), https://rm.coe.int/16806fe9aa (providing an "Asylum Applications" table in the Annex) [hereinafter COMMUNiCATION FROM GreECE].

${ }^{86}$ COMMUNICATION FROM ICJ \& ECRE, supra note 34 , at 2-3.

${ }^{87} \mathrm{Id}$. at $5-7$.

${ }^{88}$ Communication from the Greek Council for Refugees, supra note 37, at 1-3.

${ }^{89} \mathrm{Id}$. at $4-5$.

${ }^{90} \mathrm{Id}$. at $6-9$.

${ }^{91}$ They particularly worried about the obligation to ensure that the asylum procedure would be administered entirely by civil servants. See ACtion Plan-Communication by Greece, supra note 49, at 14.

${ }^{92}$ COMMUNiCATION FROM GREeCE, supra note 85.
} 
capacity of detention centers and the living standards therein, reforming the reception and identification services to ensure better care and rights protection, and overhauling the asylum procedure to respond more adequately to the high number of applications. ${ }^{93}$ At the same time, Greece acknowledged that a number of areas needed further enhancement, such as the Skypebased system for setting registration appointments and the free-of-charge provision of legal assistance. ${ }^{94}$ More importantly, 2016 was a peak year for asylum applications because of the entry into force of the EU-Turkey Statement and the success of the resulting "massive and fast track preregistration" of applicants, which in less than two months produced 27,592 entries. ${ }^{95}$ The sudden rise in the number of applications five years after the M.S.S. judgment serves to show the continuing unpredictability of the migration inflow. Understandably, an underlying concern of the Greek authorities as of March 2017 was the sustainability of the improvements made given the renewed strain on the system. As succinctly stated in the submission, "[ $t$ ]he fragile balance achieved with great difficulty may be considerably disturbed in case of further burden, to the detriment of the rights of international protection applicants." ${ }^{\prime 6}$ It is noteworthy that a country that strived to showcase its progress in complying with the M.S.S. judgment nonetheless admitted the still-brittle character of those attainments. Furthermore, Greece explicitly asserted that it "cannot accept transfers of asylum seekers, as their management would place further pressure on the asylum and reception system." 97 This is a striking declaration, as it was made in the context of the Council of Ministers review which has no direct relation to the Dublin system. It proves, however, the resolve of the Greek authorities at that time to articulate the genuine limits of their capacity to those other Convention parties who are also EU Member States. Therefore, the submission of the Greek authorities should have had a deterrent effect on the inclination of Member States to follow the Commission's Recommendation.

Another important post-Recommendation assessment is that of the Office of the United Nations High Commissioner for Refugees (UNHCR), whose findings were accepted by the ECtHR in the M.S.S. judgment as veritable depictions of the situation on the ground. Moreover, the 2009 UNHCR letter advising against transfers to Greece was used by the Court to refute Belgium's objection to responsibility-bearing under the Convention. ${ }^{98}$ The UNHCR Recommendations to Greece as of February 2017 were based on the premise that the country had not yet succeeded in eliminating the causes of "significant protection and safety risks" to asylum seekers, as it continued to provide "emergency response" rather than a fully-fledged asylum system. ${ }^{99}$ On the aspects most pertinent to the M.S.S. judgment, the UNHCR found considerable room for improvement: Enhancing the living conditions, which partly remained substandard on the mainland and "inhumane" on the islands; ${ }^{100}$ guaranteeing that detention is brought down to a minimum in practice; ensuring that the state's asylum services have sufficient capacity to process applications swiftly and without discrimination; and upgrading the asylum system's overall functioning through integrated procedures among the institutions and between the authorities and IOs and NGOs. ${ }^{101}$ As a whole, the UNHCR recommendations reveal that the national arrangements for asylum processing were yet to be converted

\footnotetext{
${ }^{93} I d$.

${ }^{94}$ Id. at $17,21,27$.

${ }^{95} \mathrm{Id}$. at $17-18$.

${ }^{96} \mathrm{Id}$. at 1 .

${ }^{97} I d$.

${ }^{98}$ M.S.S., 2011 I Eur. Ct. H.R. at para. 349.

${ }^{99}$ U.N. High COMm'r FOR RefugeEs, UNHCR ReCOMMENDATIONS FOR GREECE IN 2017 (2017), http://www.unhcr.org/ 58d8e8e64.pdf [hereinafter UNHCR RECOMMENDATIONS FOR GREECE IN 2017].

${ }^{100} \mathrm{With}$ respect to reception capacity on the Greek islands, in November 2017, the European Commission acknowledged that Greece was experiencing "another situation of severe overcrowding." Commissioner Avramopoulos, European Agenda on Migration: Remarks by Commissioner Avramopoulos on Consolidating the Progress Made, EuR. Comm’N (Nov. 15, 2017), http://europa.eu/rapid/press-release_SPEECH-17-4688_en.htm.

${ }^{101}$ UNHCR RECOMMENDATIONS FOR GREECE IN 2017, supra note 99, paras. 1-3, 6.
} 
from reactive ones, coping with the migration inflow as the need arises, into a regulated, streamlined system with built-in capacity expansion mechanisms for rapid increases of the workload. In fact, the account of the UNHCR is not dissimilar from that of the Greek authorities, as both remarked on the improvements to date, but considered that the required transformation was neither complete, nor sufficiently resilient to eliminate concerns.

The conclusions of the Greek Ombudsman as of April 2017 are comparable to the UNHCR's assessment, though marked by strong criticism towards the national authorities. Like the UNHCR, the Ombudsman noted that operations were carried out "in a state of emergency, which results in ad hoc arrangements and allows procedures ... in derogation from the applicable institutional framework." ${ }^{02}$ According to this account, the problems were at least partly attributable to the authorities themselves, as heightened regulatory activity was not always conducive to dependable and practical solutions. ${ }^{103}$ In addition to the observation of changes made on the go-which may simply be the result of zealous efforts to overcome the present difficulties - the report hinted at a larger issue with Greece's attitude towards migration. According to the Ombudsman, the authorities may have adopted certain approaches - cognizant of their non-compatibility with the human rights standards - in order to dissuade future applicants from entering the country. Specifically, the Ombudsman established that administrative detention persisted and remarked that "the actual implementation and excessive use of this measure raises the legitimate question if it actually aims at deterring the migration wave into Europe."104 Troublingly, the report tells of a general tendency of "insouciance" towards human rights, which was also manifested in the living conditions, to which migrants and asylum seekers were exposed. ${ }^{105}$ As to the asylum procedure, the Ombudsman commended the efforts of the authorities to meet the immense workload in 2016, resulting from the closing of the Western Balkan route and from the EU-Turkey Statement, while pointing out that a number of weaknesses needed to be addressed in order to secure an accessible system and effective review of applications. ${ }^{106}$ On the whole, this comprehensive evaluation of the work of the Greek authorities recognized the improvements achieved so far, while posing seriousat times even disconcerting-questions about the current attitudes in the country on human rights issues. The highlighted shortcomings should be sufficient to give pause to the other Member States, rather than encourage the application of the Commission's Recommendation to resume transfers.

Furthermore, the June 2017 pronouncement of the CoE Ministers' Deputies on the implementation of the M.S.S. judgment should be taken into account. In contrast to the optimistic outlook of the European Commission, which led to the Recommendation to renew transfers, the Ministers' Deputies did not find sufficient proof of stability in the achieved progress in order to advise closing of the review. Drawing on the opinion of the UNHCR, they decided that the Greek state had yet to demonstrate that "the current emergency response [is] transformed to a sustainable system." ${ }^{\text {" } 107}$ In particular, the Deputies highlighted the need for a plan to manage the application workload in a timely fashion given the rise in applications pending a decision at first instance-from 28,030 as of December 31, 2016 to 31,122 a month later. ${ }^{108}$ The Ministers' Deputies also requested additional information from the national authorities regarding the conditions of detention. ${ }^{109}$ In reaching those

\footnotetext{
${ }^{102}$ The Greek Ombudsman Independent Authority, Migration Flows and Refugee Protection: Administrative Challenges and Human Rights Issues 9 (Lambros Baltsiotis et al. eds., 2017), https://www.synigoros.gr/resources/docs/ greek_ombudsman_migrants_refugees_2017_en.pdf.

${ }^{103} \mathrm{Id}$. at $10-11$ (talking about "the impression of an administration striving to meet demands that appear to constantly overwhelm it").

${ }^{104} \mathrm{Id}$. at 57.

${ }^{105} I d$. at $89-90$.

${ }^{106} I d$. at $31-35$.

${ }^{107} 1288^{\text {th }}$ Meeting, 6-7 June 2017 on H46-15 M.S.S. and Rahimi Groups v. Greece (Application No. 30696/09), MINISTERS' DEPUTIES (June 7, 2017), https://search.coe.int/cm/Pages/result_details.aspx?ObjectId\%3d090000168070e978.

${ }^{108} I d$.

${ }^{109} I d$.
} 
conclusions, the Deputies had multiple submissions at their disposal, indicating varying degrees of satisfaction with the improvements made by Greece. Tellingly, the Deputies cited the UNHCR Recommendations of February 2017, which point to a continually overwhelmed asylum system, ${ }^{110}$ instead of the April 2017 statement of the UNHCR, which concurred with the Commission Recommendation that transfers could be renewed if the Greek authorities provide individual assurances. ${ }^{11}$ The approach of the Ministers' Deputies-compared to that of the European Commission - could be seen as more cautious towards human rights protection or more demanding towards the responsibilities of states. In any case, the continued monitoring of the situation in Greece signals that the standards of the European Convention on Human Rights are not yet fully met. After all, it was the violation of Convention provisions that resulted in the suspension of the Dublin system.

A later exchange between the Greek authorities and an NGO further confirms previous concerns about the capacity of the country to provide adequate living conditions and procedures not only to the asylum seekers already present, but also to those subject to future Dublin transfers. In its reproachful submission of June 2017, Open Society Justice Initiative noted the continuing serious problems in all three areas, for which Greece was found to be in violation of the European Convention on Human Rights, and attributed the unsatisfactory results to the "lack of political will of both Greece and the EU." "12 The NGO drew particular attention to the Commission Recommendation observations on substandard practices and to the admission by Greece that the acceptance of Dublin returns would exceed its capacity. ${ }^{113}$ Consequently, the organization was adamant that the resumption of transfers, before the $\mathrm{CoE}$ Committee of Ministers has confirmed the performance of Greece's human rights obligations under the M.S.S. judgment, would be "unlawful." 114

In response, the national authorities stated that considerable improvements had been made with regard to the asylum application process - in its accessibility, duration, and legal aid availabilityand asserted that the country's procedure was "one of the leanest in the European Union."115 Nonetheless, Greece complained of the continuing pressure on its asylum system from the high inflow in 2016 and 2017, and of the lack of an EU burden-sharing mechanism to alleviate it. Without such a mechanism, the authorities warned, "Greece will never be in a position to handle all asylum applications by persons seeking protection in the EU who enter the EU through Greece, irrespective of all its good faith efforts." ${ }^{116}$ With its vehement declaration, Greece demanded that solidarity is ensured within the Union before additional requirements are set before this external border state. In the spring of 2019, the Greek authorities presented a detailed update, which once again underlined the progress made on all three counts for which the country was sanctioned by the ECtHR in the M.S.S. ruling. ${ }^{117}$ At the same time, Greece drew attention to the immense recent inflow that was putting constant pressure on the reception capacity and on the processing of asylum applications. ${ }^{118}$ The authorities' conclusion was that the Common European Asylum System needed

\footnotetext{
${ }^{110}$ The Recommendations estimate the timeframe for processing the applications of individuals pre-registered in the summer of 2016 on the mainland to two years. See UNHCR RECOMMENDATIONS FOR GreECE IN 2017, supra note 99, at para. 1.

${ }^{111}$ Secretariat of the COMM. Of Ministers, Communication From AN IGO (UNHCR) (05/05/2017) IN THE CASE OF M.S.S. v. BELGIUM AND GREECE (APPLICATION No. 30696/09) (2017), https://rm.coe.int/1680717876.

112 Secretariat of the Comm. of Ministers, Communication from a NGO (The Open Society Justice Initiative) (09/08/2017) in the Case of M.S.S. v. Belgium and Greece (Application No. 30696/09) 2 (2017), https://rm.coe.int/ $168073 \mathrm{e} 373$ [hereinafter Communication from the Open Society Justice Initiative].

${ }^{113} \mathrm{Id}$. at $6-7$.

${ }^{114} I d$. at 7.

${ }^{115}$ Secretariat of the Comm. of Ministers, Communication from the Authorities (07/09/2017) Following a Communication from a NGO in the Case of M.S.S. v. Belgium and Greece (Applications No. 30696/09) (2017), https://rm.coe.int/1680743603.

${ }^{116} I d$.

${ }^{117}$ Secretariat of the Comm. of Ministers, Communication from Greece Concerning the M.S.S. AND RAHIMI Groups of Cases v. Greece (Applications No. 30696/09, 8687/08) (2019), https://rm.coe.int/168093cef7.

${ }^{118} I d$. at $52-53$.
} 
reform in order to balance the responsibilities of the EU Member States. ${ }^{119}$ The country's stancevoiced in 2017 and reiterated in 2019-not only provides a resounding answer to the suggestion for reinstatement of Dublin transfers, but also poses the crucial question of the direction in which the Commission should concentrate its efforts. Precisely that is the next element under analysis.

\section{F. A Matter of Priorities}

The Commission Recommendation is problematic because it advised the resumption of transfers despite multiple serious indications that some of the systemic issues engaging the Greek state's responsibility in the M.S.S. judgment had not been completely resolved. The explanation for that approach could be found in the Recommendation itself, which acknowledged that the principal objective was the restoration of the Schengen area in its pre-crisis form, an essential element of which is the Dublin system. ${ }^{120}$ As of April 2019, some Schengen Member States with re-introduced border controls still cited "threats resulting from the continuous significant secondary movements" as a reason for that temporary measure. ${ }^{21}$ Ironically, it was the Dublin system-not understood narrowly as the physical transfer of applicants, but as the overall obligation of the border Member States to process the claims of asylum seekers-that put an unsupportable strain on Greece in the first place. While the Commission believes that the suspension of transfers since 2011 has encouraged "secondary movements" to the other Member States, because applicants could not be turned back, it should not be forgotten that the M.S.S. case concerned just such an illegal passage even though transfers were still in force, as evidenced by the actions of Belgium. ${ }^{122}$ The most disquieting aspect is the impression that the Commission was guided by a rules-based, rather than a rights-based, approach in asserting that the "full resumption of Dublin transfers to Greece... remains the ultimate goal." 123 A similar opinion has been expressed in a European Parliamentsponsored overview of Dublin reform, in which Francesco Maiani stated that the Commission perceives systemic flaws at the national level as problems of the Dublin system rather than human rights issues. ${ }^{124} \mathrm{He}$ has even made a case that the Commission's preoccupation with the Dublin rules contradicts the values of the Common European Asylum System, as set down in primary EU law. ${ }^{125}$ Indeed, the European Commission's insistence on the reinstatement of a system, which clearly was not adequately designed to meet the exigencies of $21^{\text {st }}$ century migration waves, is a core problem.

Admittedly, the Commission has identified as a "priority" the need for "solidarity and fair burden-sharing," which should translate into a recast regulatory framework. ${ }^{126}$ The negotiations on the proposed reform have stalled for political reasons stemming from the Member States, not the Commission. ${ }^{127}$ Nonetheless, if solidarity was of paramount importance to the Commission, there would hardly be such an emphasis on restoring the Dublin system, now that its flaws have become

\footnotetext{
${ }^{119} I d$. at 52 .

${ }^{120}$ Recommendation 2016/2256, supra note 14, at recital 32.

${ }^{121}$ Migration and Home Affairs, Temporary Reintroduction of Border Control, EuRopean Commission (Apr. 30, 2019), https://ec.europa.eu/home-affairs/what-we-do/policies/borders-and-visas/schengen/reintroduction-border-control_en.

${ }^{122}$ According to various authors, secondary movements result from the inherently unequal appeal of the various EU Member States due to a combination of personal, social, economic, and asylum policy factors. See FrANCESCO MAIANI, The Reform of THE Dublin III Regulation 21-22 (2016), http://www.europarl.europa.eu/RegData/etudes/STUD/2016/ 571360/IPOL_STU(2016)571360_EN.pdf; Den Heijer, Rijpma \& Spijkerboer, supra note 7, at 608-10.

${ }^{123}$ Recommendation $2016 / 2256$, supra note 14 , at recital 33.

${ }^{124}$ MAIANI, supra note 122 , at 37.

${ }^{125} \mathrm{Id}$. at 38 .

${ }^{126}$ Recommendation 2016/2256, supra note 14, at recital 32.

${ }^{127}$ For vivid portrayals of the level of discord between the Member States, see Catherine Stupp, Migration Row Mars EU Summit, Exposes Divides, EuRACTIV (Dec. 15, 2017), https://www.euractiv.com/section/global-europe/news/eu-leaders-findno-agreement-on-migration-at-council-summit/; Robert-Jan Bartunek, Italian HardLine Overshadows EU Migration Reform Talks, REUTERS (June 5, 2018), https://www.reuters.com/article/us-europe-migrants-italy/italian-hard-line-overshadows-eumigration-reform-talks-idUSKCN1J12HK.
} 
painfully obvious. ${ }^{128}$ In fact, as the European Parliament has acknowledged, the Dublin system was not conceived as a solidarity instrument, and it has "largely failed to achieve its two primary goals of establishing objective and fair criteria for allocation of responsibility and of providing swift access to international protection." ${ }^{29}$ In the academic literature, the Regulation has repeatedly been decried as an instrument favoring efficiency over the protection of asylum seekers' rights. ${ }^{130}$

To be sure, the Dublin framework for transfers has long been under harsh critique in the academic circles on a number of grounds. ${ }^{131}$ In particular, scholars have repeatedly denounced the lack of adequate burden-sharing in the very design of the system. ${ }^{132}$ It has even been hinted that the strain under which the southern and eastern Member States might come was fully understood, and a political choice was made to the benefit of the inner countries. ${ }^{133}$ While the latter claim seems rather implausible, or at least unsubstantiated, the unequal load on the Member States has become self-evident. In the wake of the M.S.S. and N.S. judgments, the scholarship has argued that the rights-protection obligations, asserted by the ECtHR and CJEU, necessitated a robust mechanism for transfer suspension. ${ }^{134}$ It has even been suggested that if the EU would accede to the European Convention on Human Rights, it might be held responsible for violations of asylum seekers' rights due to the absence of a preventive mechanism. ${ }^{135}$ In the end, what the Dublin III Regulation of 2013 did provide was a mechanism for early warning, preparedness, and crisis management. ${ }^{136}$ Under that mechanism, a Member State, which has asylum system issues or may soon face considerable inflow, shall be directed by the EU institutions on how to address the situation. The mechanism, however, cannot be classified as a burden-sharing tool. ${ }^{137}$ Furthermore, the originally envisaged transfer suspension option was edited out of the final version of the Dublin III Regulation, leading to criticism about the continuing impact of the Dublin system on the rights of asylum seekers. ${ }^{138}$

Unfortunately, the lack of fundamental reforms also holds true for the proposed recast of the Dublin III Regulation for determining the responsible Member State. ${ }^{139}$ The Dublin IV scheme reemphasizes the first point of entry as a key criterion. ${ }^{140}$ As Francesco Maiani has pointed out, the

\footnotetext{
${ }^{128}$ Scholars have argued that the underlying causes of the migration crisis have been the EU's policy response and the inability to seek novel solutions, rather than the sheer numbers of incoming asylum seekers. See Den Heijer, Rijpma \& Spijkerboer, supra note 7, at 641-42.

${ }^{129}$ Resolution on the Situation in the Mediterranean and the Need for a Holistic EU Approach to Migration 15, EUR. PARL. Doc P8_TA(2016)0102 (2016), http://www.europarl.europa.eu/doceo/document/TA-8-2016-0102_EN.pdf [hereinafter European Parliament Resolution of 2016].

${ }^{130}$ James C. Hathaway, E.U. Accountability to International Law: The Case of Asylum, 33 MiCH. J. INT'L L. 1, 7 (2011); Lavrysen, supra note 24, at 241; Joanna Lenart, 'Fortress Europe': Compliance of the Dublin II Regulation with the European Convention for the Protection of Human Rights and Fundamental Freedoms, 28 MERKOURIOS: UTRECHT J. INT'L \& Eur. Migration L. 4, 5 (2012).

${ }^{131}$ For a concise, yet thorough, review of the main arguments against the Regulation in its 2003 version applicable to the M.S.S. judgment, see Lavrysen, supra note 24, at 220-22. Further discussion of the most problematic aspects of the Dublin II Regulation - from the point of view of fundamental rights and asylum rights - may also be found in Lenart, supra note 130, at 12-17. A convincing argument about the key structural flaws of the Dublin system is made by MAIANI, supra note 122, at $20-26$.

${ }^{132}$ Clayton, supra note 48, at 760; Costello, supra note 12, at 92; Lenart, supra note 130, at 13.

${ }^{133}$ Lenart, supra note 130 , at 5-6.

${ }^{134}$ Costello, supra note 12, at 92; Lavrysen, supra note 24 , at 225.

${ }^{135}$ Lavrysen, supra note 24, at 226.

${ }^{136}$ Regulation 604/2013, art. 33.

${ }^{137}$ Den Heijer, Rijpma \& Spijkerboer, supra note 7, at 613.

${ }^{138}$ Mitsilegas, supra note 16 , at 197-98.

${ }^{139}$ Proposal for a Regulation of the European Parliament and of the Council Establishing the Criteria and Mechanisms for Determining the Member State Responsible for Examining an Application for International Protection Lodged in One of the Member States by a Third-Country National or a Stateless Person (Recast), EuropeAn Commission, COM (2016) 270 (May 4 , 2016).

${ }^{140}$ See id. at ch. III.
} 
prominence of the "irregular entry" criterion has always been unfair from the perspective of logic, human rights protection, and EU solidarity. ${ }^{141}$ In the Dublin IV proposal, he warned, the use of the criterion is coupled with an all-new set of tasks for the frontline Member States, which will not only fail to alleviate the situation, but may even exacerbate it. ${ }^{142}$ Although the draft provides for a corrective allocation mechanism on which overwhelmed Member States could rely, the measure has been criticized as too difficult to activate. ${ }^{143}$ Furthermore, the suggested revision might be seen as an expedient for reinstating the Schengen Area, as the corrective mechanism would come into force only after the border states have evaluated the preliminary acceptability of asylum applications - in other words, after those countries have already performed certain procedural tasks. ${ }^{144}$ According to the draft, secondary movements are supposed to be prevented and remedied through a stricter system of penalties on asylum seekers. ${ }^{145}$ Therefore, the proposed recast of the Dublin III Regulation falls short of the overhaul, which one might have expected in response to the human rights obligations of the Union and its Member States. A comprehensive overview of the reform debate is outside the scope of the present Article, but it is important to outline the general direction of the discourse. While the academic literature has not arrived at the exact form of a truly improved Dublin system, the emerging message points to the need for stimuli, which would secure the cooperation of Member States and asylum seekers alike. ${ }^{146}$ Specifically, propositions include asylum claim distribution reflecting Member States' capacities, additional financial support for the frontline countries, and criteria that account for asylum seekers' individual preferences. ${ }^{147}$ From this perspective, the Dublin IV proposal does not go far enough.

To eradicate the underlying problems of the Dublin system, the European Commission should have proposed a complete redesign along the above-listed lines, rather than a patch that largely preserves the status quo. For instance, the European Parliament has been significantly bolder in its vision for improvements, putting forward a permanent, automatic relocation mechanism based on Member States' capacity - as determined by the State's GDP and population size-with sanctions for non-compliant Member States. ${ }^{148}$ Meanwhile, the Council of the EU has been unable to reconcile the diverging positions of the Member States, repeating instead the need for a balance between responsibility and solidarity. ${ }^{149}$ As is visible from the suggestion of the Bulgarian rotating

\footnotetext{
${ }^{141}$ MAIANI, supra note 122 , at $24-25$.

${ }^{142} I d$. at 6,36 .

${ }^{143}$ In their opinions on the proposal, both the Committee of the Regions and the Economic and Social Committee have asserted that the threshold for triggering the mechanism is too high, which would diminish its practical usefulness. See Opinion of the European Committee of the Regions-Reform of the Common European Asylum System, 2017 O.J. (C 185) 91; Opinion of the European Economic and Social Committee on the 'Proposal for a regulation of the European Parliament and of the Council establishing the criteria and mechanisms for determining the Member State responsible for examining an application for international protection lodged in one of the Member States by a third-country national or a stateless person (recast)', 2017 O.J. (C 34) 144.

${ }^{144}$ Corinne Balleix, Dublin and Schengen-Restoring Confidence and Strengthening Solidarity between Member States of the European Union, Eur. Issues \& INTERVIEws (May 15, 2017), https://www.robert-schuman.eu/en/european-issues/0434dublin-and-schengen-restoring-confidence-and-strengthening-solidarity-between-member-states-of; MAIANI, supra note 122 , at $36-37$.

${ }^{145}$ MAIANI, supra note 122 , at 35-37, 42-43.

${ }^{146}$ Den Heijer, Rijpma \& Spijkerboer, supra note 7; Andrei Dragan, Dublin III and Beyond: Between Burden-Sharing and Human Rights Protection, 2 PÉCS J. INT'L \& Eur. L. 84 (2017).

${ }^{147}$ Maiani, supra note 122, at 8, 53-56; Marcello Di Filippo, From Dublin to Athens: A Plea for a Radical Rethinking of the Allocation of Jurisdiction in Asylum Procedures (2016), http://immigrazione.jus.unipi.it/wpcontent/uploads/sites/3/2016/02/IIHL-A-plea-for-the-reform-of-the-Dublin-system-policy-brief-def.pdf.

${ }^{148}$ Report on the Proposal for a Regulation of the European Parliament and of the Council Establishing the Criteria and Mechanisms for Determining the Member State Responsible for Examining an Application for International Protection Lodged in One of the Member States by a Third-Country National or a Stateless Person (Recast), A8-0345/2017 (Nov. 6, 2017). The European Parliament's negotiating mandate for reform of the Dublin system was adopted on November 16, 2017.

${ }^{149}$ See Note from the Presidency to the Permanent Representatives Committee/Council, CounCIL OF THE EUROPEAN UNION 9781/17 (June 2, 2017).
} 
Presidency, dated late May 2018, the Member States view the end of secondary movements as the cornerstone of reorganizing the entire Common European Asylum System. ${ }^{150}$ On the one hand, the Bulgarian delegation made an effort to ensure greater solidarity through a crisis mechanism in case a Member State experiences a significant migratory pressure, which would then trigger automatic financial, technical, operational, and expert support. ${ }^{151}$ On the other hand, the main characteristics of the current Dublin system would be further entrenched, namely the criteria for responsibility allocation, the resulting obligations for the designated Member States, and the penalties for secondary movements. ${ }^{152}$ The negotiating mandate of the Council has not been settled yet. The European Council meeting in June 2018 - which could have been a breakthrough moment-simply confirmed the lack of consensus on the recast of the Dublin III Regulation. ${ }^{153}$ Nevertheless, it seems that a concept of strict rule enforcement will be at the center of the Council's ultimate position.

The European Commission-facing uncertain prospects for adoption of its proposal before the end of its term - has settled for a pragmatic approach, compared to its initial ideas. It announced that relocation shall only be mandatory for the Member States in times of crises, with voluntary commitments applying in less difficult circumstances. ${ }^{154}$ Evidently, the Commission shall not attempt an ambitious revision of the Dublin system, choosing instead to seek whatever progress is possible. While that may prove to be the only way forward from a procedural viewpoint, it would signal that the determination to reboot the scheme has trumped the drive for a qualitative change of a system that yields unsatisfactory, and at times dangerous, results.

Furthermore, the approach towards transfer resumption exposes the use of a double standard. Greece, as a border country, shall be obligated to wait as long as it takes for the other Member States to agree to recast the Directives and take on some of the burden. At the same time, the Commission is unwilling to postpone the transfers until Greece establishes fully-functioning, sustainable arrangements for the treatment of asylum seekers and their claims. It is crucial to recognize that in the absence of reform, the Dublin rules - though placing a clearly inequitable workload on the Member States-are legally valid. The Court of Justice of the EU asserted that validity in its judgment in Case C-646/16 Jafari, which firmly rejected the handover of the asylum processing task from Croatia to Austria, even if there was an influx of an "unusually large number of third-country nationals" seeking protection. ${ }^{155}$ While the Court reiterated that human rights protection constitutes an exception to the transfer rules, ${ }^{156}$ those rules were nonetheless upheld. In fact, the responsibility of the first-entry Member State was hailed as an example of the accountability of that country to the others, as its duty to "bear the consequences thereof in a spirit of solidarity and fair cooperation." ${ }^{157}$ As the CJEU acknowledged, the alternative would not only contradict the express wording of the Dublin III Regulation, but it would also undermine its very rationale. ${ }^{158}$ The Court's optimism ${ }^{159}$ as to the Union's capability for emergency response towards mass migration does not seem to be borne out by reality. Neither do the references to "solidarity"

\footnotetext{
${ }^{150}$ Note from the Presidency to the Council, Council of the European UnION 9520/18 (May 30, 2018), at pts. 11-14.

${ }^{151} I d$. at pts. 20, 21, 24, Annex II.

${ }^{152} I d$. at pts. $23-24$, Annexes I, IV.

${ }^{153}$ European Council Press Release 421/18, European Council Conclusions (June 28, 2018), http://www.consilium.europa. eu/en/press/press-releases/2018/06/29/20180628-euco-conclusions-final/pdf.

${ }^{154}$ European Commission Press Release IP/17/5123, Future-Proof Migration Management: European Commission Sets Out Way Forward (Dec. 7, 2017) http://europa.eu/rapid/press-release_IP-17-5132_en.htm.

${ }^{155}$ ECJ, Case C-646/16, Jafari v. Bundesamt für Fremdenwesen und Asyl, ECLI:EU:C:2017:586, Judgment of 26 July 2017 , paras. 87-94.

${ }^{156}$ Where a genuine risk of inhuman or degrading treatment arises due to a mass inflow of asylum seekers. Jafari, Case C$646 / 16$ at para. 101.

${ }^{157} \mathrm{Id}$. at para. 88 .

${ }^{158} \mathrm{Id}$. at paras. $89,97$.

${ }^{159} I d$. at paras. 94-101. The CJEU listed several measures that could theoretically avert or allay the occurrence of insupportable pressure on the asylum system of a Member State in case of a sudden and large inflow.
} 
in the recitals of the various legal acts equal effective mutual assistance or partnership. ${ }^{160}$ The judgment does, however, prove that any alteration of the Dublin system should be sought through legislative initiatives, not court challenges of the acts in force. Therefore, the European Commission should direct its efforts for fairer burden-sharing towards fundamentally reforming the Dublin rules as a matter of priority.

With respect to temporarily remedying the solidarity deficit, two Council Decisions on relocation $^{161}$ adopted in 2015 should, in principle, have resulted in a more even distribution of the asylum pressure across the Member States by relocating a total of 160,000 asylum applicants from Greece and Italy by September 26, 2017. Unfortunately, that relief measure has turned out to be less effective than originally planned. Eventually, a total of 34,691 people were relocated-21,999 from Greece ${ }^{162}$ _despite a final legal commitment for 98,255 relocations-with 63,302 expected to be relocated from Greece. ${ }^{163}$ The European Commission has hailed the result as evidence that the EU relocation scheme was a "success," citing a relocation rate of " $96 \%$ of eligible persons." 164 It has been pointed out, however, that the criteria for relocation eligibility considerably narrowed down the potential for large-scale alleviation of the burden placed on the countries of first entry. ${ }^{165}$ Furthermore, Poland, Hungary, and the Czech Republic have not performed their relocation obligations - at the cost of triggering infringement procedures against themselves. ${ }^{166}$

In this context, it is not surprising that Greece seems to view itself as abandoned in its plight. According to the March 2017 submission of the Greek authorities, "other Member States, including those with high level of know-how, sufficient resources and organized infrastructure, have failed to fully meet their obligations for the provision of assistance to Greece. . regarding the number of asylum experts. .. or for providing relocation spaces."167 The Greek authorities identified the relocation issues, along with the surge in asylum applications in 2016, as the two key factors threatening the progress achieved by the country thus far. ${ }^{168}$ In this respect, the Greek Ombudsman - who did not spare criticism towards the domestic authorities' response to the migration crisis - also noted "the substantial refusal of certain Member States to comply" with the relocation arrangements and "the inability of the EU institutional structure to ensure implementation of the commitments." ${ }^{69} \mathrm{He}$ even pointed to "the loss of the credibility of the relocation

\footnotetext{
${ }^{160}$ For a review of the EU legal provisions mandating solidarity in the area of asylum, see Paul McDonough \& Evangelia (Lilian) Tsourdi, The "Other" Greek Crisis: Asylum and EU Solidarity, 31 RefugEe SuRV. Q. 67, 74-76 (2012).

${ }^{161}$ Council Decision 2015/1523 of Sept. 14, 2015, Establishing Provisional Measures in the Area of International Protection for the Benefit of Italy and of Greece, 2015 O.J. (L 239) 146 (EU); Council Decision 2015/1601 of Sept. 22, 2015, Establishing Provisional Measures in the Area of International Protection for the Benefit of Italy and Greece, 2015 O.J. (L 248) 80 (EU).

${ }^{162}$ U.N. High COMm'r for Refugees, Europe Monthly RePORT-June 2018, at 2 (2018), https://data2.unhcr.org/ar/ documents/download/65078.

${ }^{163}$ European Commission Fact Sheet MEMO/17/349, Questions and Answers: Commission Calls for Renewed Efforts in Implementing Solidarity Measures under the European Agenda on Migration, (Mar. 2, 2017).

${ }^{164}$ Progress Report on the Implementation of the European Agenda on Migration, at 17, COM (2018) 301 (May 16, 2018).

${ }^{165}$ European Parliament Resolution of 2016, supra note 129, at 13; MAIANI, supra note 122, at 19; see also GREEK Ombudsman Independent Authority, Relocation Revisited: The Greek Case 45-50 (Aeverie J. Polintan ed., 2019), https://www.synigoros.gr/resources/docs/20190215-relocation-go-report.pdf (delivering data-driven findings relevant to this point).

${ }^{166}$ On December 7, 2017, the European Commission announced that it had decided to refer the three countries to the Court of Justice of the EU. See European Commission Press Release IP/17/5002, Relocation: Commission Refers the Czech Republic, Hungary and Poland to the Court of Justice, (Dec. 7, 2017) http://europa.eu/rapid/press-release_IP-17-5002_en.htm. Importantly, on September 6, 2017, the CJEU dismissed the challenges by Slovakia and Hungary against one of the Council DecisionsDecision 2015/1601 - establishing a provisional mechanism for mandatory relocation. See ECJ, Joined Cases C-643/15 \& C-647/15, Slovak Republic \& Hungary v. Council of the European Union, ECLI:EU:C:2017:631, Judgment of 6 Sept. 2017.

${ }^{167}$ COMMUNICATION FROM GREECE, supra note 85 , at 31.

${ }^{168} \mathrm{Id}$. at $1-2$.

${ }^{169}$ Greek Ombudsman Independent Authority, Migration Flows and Refugee Protection, supra note 102 , at 36. Disappointment with the results of the relocation scheme, given its considerably greater potential, is also expressed in the Ombudsman's 2019 follow-up report-GREEK OMBUDSMAN INDEPENDENT AUTHORITY, RELOCATION REVISITED, supra note 165.
} 
program," according to the perceptions of the Greek Asylum Service. ${ }^{170}$ In short, the European Commission's attempts at providing reprieve to Greece have proved to be less impactful than initially envisioned.

While the non-cooperation of some Member States with the relocation commitments might bring about judicial sanctions against them eventually, many States have already signaled their readiness to resume the Dublin transfers. Following the Commission Recommendation, fourteen countries within the Dublin system sent transfer requests to Greece in $2017 .{ }^{171}$ In total, the country received 2,134 incoming requests in 2017, and 9,142 requests in 2018 under the Dublin procedure. ${ }^{172}$ One transfer to Greece was performed in 2017, and eighteen - in 2018. ${ }^{173}$ Even though the actual transfer numbers are still low, the figures indicate a clear interest of the other Member States in resuming the returns of asylum seekers.

A stark embodiment of this interest is the Administrative Arrangement between the Greek Ministry of Migration Policy and the German Interior Ministry concluded in August 2018 and kept concealed from public scrutiny by the authorities of the two states. ${ }^{174}$ In short, the agreement provides for a speedy, near-automatic return to Greece of asylum seekers who are not unaccompanied minors and who have applied for protection in Greece post-June 2017, but have moved on and unsuccessfully sought entry into Germany at the border with Austria. ${ }^{175}$ In exchange, Germany will quickly handle pending/accepted "take charge" requests from Greece, as well as pending reexamination requests. ${ }^{176}$ As of early March 2019, Germany had returned nine asylum seekers to Greece under the agreement. ${ }^{177}$ The Administrative Arrangement has drawn severe criticism on several counts, namely the ambiguous legal status of the agreement, the substitution of the EU-wide Dublin rules with bilateral transfers under an expedited procedure, the resulting reduction of safeguards for asylum seekers' rights, and the political implications of setting up a parallel system when negotiations on Dublin reform have come to a deadlock. ${ }^{178}$ Indeed, the agreement, which served as an expedient for resolving Germany's internal political crisis in mid-2018, ${ }^{179}$ circumvents the procedural rights of asylum seekers under the Dublin system to appeal the decisions of the German authorities before being flown back to Greece. The new rules eliminate the issuance of individual assurances and remove the possibility for a substantive court assessment of the human rights risks deriving from transfers. From a policy perspective, bilateral agreements undermine the common efforts to recast the Dublin III Regulation. Similarly to the problems with the relocation scheme and the standoff in the Dublin IV negotiations, national self-interest threatens to supersede EU-wide solidarity.

\footnotetext{
${ }^{170}$ Greek Ombudsman Independent Authority, Migration Flows and Refugee Protection, supra note 102 , at 36.

${ }^{171}$ European Asylum Support Office, ANNUAl Report on the Situation of AsYlum in the European UNiON 2017 67 (2018), https://www.easo.europa.eu/sites/default/files/Annual-Report-2017-Final.pdf.

${ }^{172}$ Hellenic Republic Ministry of Migration Policy Asylum Serv., Statistical Data of the Greek Dublin Unit (7.6.2013 - 28.02.2019) (2019), http://asylo.gov.gr/en/wp-content/uploads/2019/03/Dublin-stats_February19EN.pdf.

${ }^{173} \mathrm{Id}$.

${ }^{174}$ The Arrangement was leaked by a Greek NGO. See The Administrative Arrangement Between Greece and Germany, REFUGEE SUPPORT AEGEAN (Nov. 1, 2018), https://rsaegean.org/en/the-administrative-arrangement-between-greece-andgermany/.

${ }^{175} I d$. at pts. 1,3 .

${ }^{176} I d$. at pts. 7,9 .

${ }^{177}$ Bisher Nur Elf Asylbewerber an Grenze Abgewiesen [So far only Eleven Asylum Seekers Rejected at the Border], SPIEGEL (Mar. 3, 2019), http://www.spiegel.de/politik/deutschland/fluechtlinge-bisher-nur-elf-asylbewerber-an-grenze-abgewiesen-a1256025.html.

${ }^{178}$ Stathis Poularakis, The Case of the Administrative Arrangement between Greece and Germany: A Tale of "ParaDublin Activity"?, Eur. DAtabase of Asylum L. (Nov. 5, 2018), https://www.asylumlawdatabase.eu/en/journal/case-administrativearrangement-between-greece-and-germany-tale-\%E2\%80\%9Cparadublin-activity\%E2\%80\%9D; EUROPEAN COUNCIL ON Refugees \& Exiles, Bilateral Agreements: Implementing or Bypassing the Dublin Regulation? Policy Paper 5 (2018), https://www.ecre.org/wp-content/uploads/2018/12/Policy-Papers-05.pdf; Constantin Hruschka, Gewolltes Recht [Desired Law], VerfassungsBlog (Nov. 2, 2018), https://verfassungsblog.de/gewolltes-recht.

${ }^{179}$ Bisher Nur Elf Asylbewerber an Grenze Abgewiesen, supra note 177.
} 
Should large-scale systematic transfers- under the Dublin rules or a bilateral deal-recommence, asylum seekers should be sent to the mainland, which provides far superior reception conditions and access to the application procedure compared to the islands, where serious problems persist under the continuous migration pressure. ${ }^{180}$ Nonetheless, the mainland is already straining, as it is running out of capacity to take on asylum seekers from the overcrowded islands and thus alleviate the hotspots. ${ }^{181}$ Human Rights Watch has insisted that relief for asylum seekers on the islands - by moving them to mainland Greece — should in no way be offset by renewed Dublin transfers. ${ }^{182}$ These circumstances indicate that Greece has a long and difficult road ahead towards providing adequate treatment for the asylum seekers located on its territory-both on the islands and on the mainland. ${ }^{183}$ Therefore, large-scale transfers from other EU Member States under the Dublin system might aggravate the situation immensely.

Nevertheless, considering the attitudes in favor of the full implementation of the Commission Recommendation on transfers, it is important to look at the proposed modalities. According to the Commission, transfers shall be based on individual assurances, to be provided by Greece, that the particular asylum seeker shall be treated in compliance with EU law, especially with regard to reception conditions and application processing. ${ }^{184}$ Although these assurances are primarily intended to guarantee respect for asylum seekers' rights, they also have another significant function-a potential release from responsibility for the acts or omissions of other Member States, should a human rights violation occur. Clear evidence is to be found in the M.S.S. judgment, where the ECtHR held Belgium responsible because the diplomatic assurances provided by Greece were not sufficiently individualized to ensure rights protection. ${ }^{185}$ Considering the serious deficiencies in the reception conditions and asylum procedure - which third parties continue to report regularly - it is questionable whether assurances would absolve another Member State of responsibility. The published accounts of recurring shortcomings in the treatment of asylum seekers might very well constitute sufficient proof for a court to decide that diplomatic assurances should have been rebutted by the sending authorities. In that case, the resumption of systematic Dublin transfers might turn out to be premature, leading to yet another suspension of the system.

To preclude such a turn of events, the courts of the other Member States might exercise additional caution and disallow the conduct of transfers. ${ }^{186}$ That already occurred in Germany in the Fall of 2017, when an administrative court prevented a Dublin transfer to Greece because of the outstanding risk of inhuman or degrading treatment, although Greece had agreed to take charge of the asylum seeker. ${ }^{187}$ Tellingly, the court pointed to the Commission Recommendation as a key source for the finding of "systemic" deficiencies in the reception conditions and asylum

\footnotetext{
${ }^{180}$ Alexandros Konstantinou \& Athanasia Georgopoulou, Greek Council for Refugees, Country Report: GreECE, 2018 UPDATE 128-31 (2019), http://www.asylumineurope.org/sites/default/files/report-download/aida_gr_2018update.pdf.

${ }^{181}$ U.N. High COMm'R fOR Refugees, Greece FACt SHeEt: Feb. 1-28, 2019 (2019), https://data2.unhcr.org/en/documents/ download/68627.

${ }^{182}$ Why Greece Should \#OpenTheIslands, HuM. RTs. WATcH (Mar. 19, 2018), https://www.hrw.org/news/2018/03/19/whygreece-should-opentheislands.

${ }^{183}$ The facts confirm Francesco Maiani's observation that, while the suspension of transfers shields asylum seekers who have traveled onward to countries offering better reception and asylum procedures, those who have not fled from a Member State with systemic flaws are exposed to hardship. See MAIANI, supra note 122, at 13.

${ }^{184}$ Recommendation 2016/2256, supra note 14 , at pt. 10, recitals 36-37.

${ }^{185}$ M.S.S., 2011 I Eur. Ct. H.R. at para. 354. That finding was one of the contentious issues, as demonstrated by the partly concurring and partly dissenting opinion of Judge Sajó and the partly dissenting opinion of Judge Bratza.

${ }^{186}$ For instance, the Belgian Council on Alien Law Litigation has, on various occasions, ruled against the transfer of asylum seekers to Bulgaria although the Dublin system is not officially suspended with respect to Bulgaria. See Vluchtelingenwerk Vlaanderen, Dublin: Belgium, Asylum Information Database, Eur. Council on Refugees \& ExiLEs (2017), http://www. asylumineurope.org/reports/country/belgium/asylum-procedure/procedures/dublin.

${ }^{187}$ Germany: Administrative Court of Düsseldorf Rules against a Dublin Transfer to Greece Based on Serious Shortcomings in the Greek Asylum System, Eur. DATABASE OF AsYlum L. (Oct. 26, 2017), http://www.asylumlawdatabase.eu/en/content/ germany-administrative-court-d\%C3\%BCsseldorf-rules-against-dublin-transfer-greece-based-serious.
} 
procedure. ${ }^{188}$ Such a ruling - while not unexpected - may deal a serious blow to the credibility of the Commission's assessments.

From a legal perspective, the ruling follows the CJEU's guidance in the N.S. judgment on disallowing transfers when there are indications of systemic deficiencies subjecting an asylum seeker to the risk of rights violations in the original responsibility-bearing state. As already mentioned, this instruction has been transposed in the currently applicable Dublin III Regulation. ${ }^{189}$ Therefore, some authors have argued that the N.S. judgment ruling transformed what was previously a discretionary power to assume responsibility for an asylum claim-the so-called "sovereignty clause"190 — into a "duty" to prevent human rights violations by taking over the claim examination. ${ }^{191}$ As Mitsilegas has rightly pointed out, however, once a transfer cannot be performed for human rights reasons, the second Member State should turn to the list of claim-distribution criteria in the Regulation; it would only have to take responsibility itself if no other state could be designated. ${ }^{192}$ The Dublin III Regulation has assigned States the task to ensure transfers do not occur if there are "substantial grounds" to believe that the asylum seeker might face inhuman or degrading treatment due to the asylum system and reception conditions of the first-entry state. ${ }^{193}$ When that threshold ${ }^{194}$ is met, however, is open to debates. For instance, in June 2018 the Belgian Council of Alien Law Litigation found that the outstanding issues with the treatment of asylum seekers and their applications by Greece did not amount to "systemic" flaws that would justify the suspension of a transfer, especially when individual assurances are provided as recommended by the European Commission. ${ }^{195}$ At the same time, the CJEU has modified the pre-emptive requirement, specifying that systemic flaws need not be present, as long as the particular circumstances of the asylum seeker demonstrate a "real and proven risk" of inhuman or degrading treatment. ${ }^{196}$ While that seemed to increase protection of asylum seekers, in 2019 the CJEU ruled that, in order to reach the threshold of inhuman or degrading treatment, the living conditions must amount to no less than "extreme material poverty." 197 In summary, the Member States are walking a thin line, when deciding whether a transfer poses a risk of human rights violations. The ultimate responsibility—not only moral, but also legal—lies with them.

\section{G. Conclusions}

The Dublin system for distribution of asylum-related tasks among the Member States was established at a moment when the scale of modern-day mass migration towards Europe was probably inconceivable. As such, the system was poorly geared to ensure an adequate response to the pressure produced by the instability in several regions of the world. That is a frequent failing of arrangements designed at times of relative calm, when little attention is paid to the risks of crises and the need for safeguards. The true strength of a system, however, lies not in its complete imperviousness, but in its swift adaptability. Once the capacity of the Greek authorities to manage the inflow of asylum seekers had been overwhelmed, it was up to the European Union to devise and

\footnotetext{
${ }^{188}$ Verwaltungsgericht Düsseldorf [VG Düsseldorf] [Administrative Court Düsseldorf] Oct. 26, 2017, Case No. 12 L 4591/ 17.A, paras. 17-23, 26-27, (Oct. 26, 2017), https://www.justiz.nrw.de/nrwe/ovgs/vg_duesseldorf/j2017/12_L_4591_17_A_ Beschluss_20171026.html.

${ }^{189}$ Regulation 604/2013, art. 3(2).

${ }^{190}$ See Council Regulation 343/2003, art. 3(2).

${ }^{191} \mathrm{Gragl}$, supra note 18 , at 8 ; Lenart, supra note 130 , at 17.

${ }^{192}$ Mitsilegas, supra note 16 , at 194-96.

${ }^{193}$ Compare Regulation 604/2013, art. 3(2) with N.S., Cases C-411/10 \& C-493/10 at para. 94.

${ }^{194}$ Some commentators have argued that the Court set the bar quite high. See Mitsilegas, supra note 16, at 192, 194; Dragan, supra note 146 , at 86 .

${ }^{195}$ Conseil du Contentieux des Etrangers [Council of Alien Law Litigation] June 8, 2018, No. 205.104, paras. 4.3.5.4, 4.3.11, http://www.rvv-cce.be/sites/default/files/arr/a205104.an_.pdf (Belg.).

${ }^{196}$ See ECJ, Case C-578/16 PPU et al. v. Republika Slovenija, ECLI:EU:C:2017:127, Judgment of 16 Feb. 2017, paras. 91-96.

${ }^{197}$ ECJ, Case C-163/17 Jawo v. Bundesrepublik Deutschland, ECLI:EU:C:2019:218, Judgment of 19 Mar. 2019, paras. 91-93.
} 
implement the requisite amendments. In fact, if a single failing is to be pointed out in the resulting state of disarray, it should probably be the inability of the Union to recast the inherently inequitable Dublin system. Ultimately, five years after the suspension of transfers, the European Commission chose to set a specific timeframe for the resumption of transfers under flawed rules, as the chances for re-negotiation of the legal framework remained uncertain.

From a purely statistical viewpoint, the likelihood that the Commission Recommendation would place an excessive burden on the Greek authorities is not remote. Official information shows that for a while the country had a tremendous progress in clearing the backlog of asylum cases, and in 2017 Greece was not in the top three Member States in Europe by absolute number of first-time asylum applications lodged. ${ }^{198}$ Nonetheless, in 2017 Greece had the highest number of first-time applicants per one million inhabitants. ${ }^{199}$ The situation escalated in 2018, when Greece ranked third in the EU by absolute number of first-time applicants and second by number of applicants relative to the country's population. ${ }^{200}$ As of the end of 2018 , Greece had a total of 76,300 asylum applications pending review at different stages. ${ }^{201}$ The re-instatement of Dublin transfers would diminish the workload of the inner Member States at the expense of the external border countries like Greece. Furthermore, capabilities vary considerably, making the purely numerical comparisons rather detached from reality. ${ }^{202}$ In the end, the Commission Recommendation and the Greek opposition to it are important, because at stake are not only the usual tensions between the EU and the national level of governance, but the fundamental rights of thousands of people_-against the backdrop of the Union's overall commitment to rights protection.

As demonstrated in this Article, notwithstanding the tangible improvements achieved by Greece so far, the reports of third-party observers still reveal deficiencies in the detention practices, reception conditions, and asylum procedure. Therefore, the most controversial aspect of this situation is the Commission Recommendation for resumption of the Dublin transfers. This impatience for the restoration of a far-from-perfect system might result in yet another negative judgment of the ECtHR. In this worst-case scenario, the non-accession of the Union to the European Convention on Human Rights might prove to be a shield against possible negative legal consequences. ${ }^{203}$ Yet, the harshest burden would be endured by the affected asylum seekers. Rights are held and enjoyed individually, so that a single violation is substantial in and of itself. While no system is perfect, one would expect higher standards and more robust guarantees from such an aspiring world leader in human rights protection as the European Union.

\footnotetext{
${ }^{198} 650,000$ First-Time Asylum Seekers Registered in 2017, Eurostat (Mar. 20, 2018), http://ec.europa.eu/eurostat/ documents/2995521/8754388/3-20032018-AP-EN.pdf/50c2b5a5-3e6a-4732-82d0-1caf244549e3.

${ }^{199} I d$.

${ }^{200} 580,800$ First-Time Asylum Seekers Registered in 2018, Down by 11\% Compared with 2017, EurosTAT (Mar. 14, 2019), https://ec.europa.eu/eurostat/documents/2995521/9665546/3-14032019-AP-EN.pdf/eca81dc5-89c7-4a9d-97ad-444b6bd32790.

${ }^{201} I d$.

${ }^{202}$ The Dublin III Regulation has been criticized for ignoring the variations in Member States' capacity to provide protection to asylum seekers. See Den Heijer, Rijpma \& Spijkerboer, supra note 7, at 613.

${ }^{203}$ For a discussion about the potential outcome of a case like M.S.S. had the EU acceded to the European Convention on Human Rights, see Gragl, supra note 18, at 10-11.
}

Cite this article: Gotsova B (2019). Rules Over Rights? Legal Aspects of the European Commission Recommendation for Resumption of Dublin Transfers of Asylum Seekers to Greece. German Law Journal 20, 637-659. https://doi.org/10.1017/ glj.2019.54 